\title{
PENERAPAN KEBIJAKAN ELEKTRONIK FAKTUR PAJAK DALAM RANGKA KEMUDAHAN PELAYANAN KEPADA WAJIB PAJAK PADA KANTOR PELAYANAN PAJAK BEKASI SELATAN
}

\author{
Mega Kusuma dan Nopikah Safitri \\ Institut Ilmu Sosial dan Manajemen STIAMI \\ megakusuma1609@gmail.com
}

\begin{abstract}
Abstrak. Pajak adalah salah satu komponen penting dari penyelenggaraan Negara karena semua aktivitas yang masuk ke kas Negara, berdasarkan hal tersebut maka menjadi penting sekali bagaimana Direktorat Jederal Pajak sebagai lembaga Negara yang membidangi urusan perpajakan dapat membuat kebijakan yang dapat memaksimalkan pemasukan pajak bagi negara, dan salah satu kebijakan yang dibuat Direktorat Jederal Pajak adalah Faktur Pajak elektronik yang disebut sebagai e-faktur yang resmi diluncurkan pada tanggal 1 Juli 2014. Munculnya kebijakan tersebut didasari oleh banyaknya penyimpangan faktur pajak yang berbentuk pajak fiktif dengan jumlah pelanggaran yang cukup tinggi. Tujuan dari penelitian ini adalah untuk mengetahui penerapan kebijakan Faktur Pajak Elektronik dakam rangka kemudahan pelayanan kepada wajib pajak pada kantor pelayanan pajak pratama Bekasi Selatan.

Jenis penelitian ini yang digunakan dalam penelitian ini adalah deskriptif dengan mengunakan pendekatan kualitatif. Hasil penelitian menunjukan bahwa Penerapan Kebijakan Elektronik Faktur Pajak Dalam Rangka Kemudahan Kepada Wajib Pajak Pada Kantor Pelayanan Pajak Pratama Bekasi Selatan secara keseluruhan cukup baik meskipun masih ada beberapa yang menghambat dalam pembuatan faktur pajak dan mempengaruhi kepatuhan wajib pajak seperti tidak meratanya sosialisasi yang dilakukan oleh kantor pelayanan pajak, server yang sering down/offline, jaringan internet yang belum stabil, pengetahuan perusahaan kena pajak yang masih kurang terkait kebijakan dan kurangnya anggota fiskus untuk mensosialisasikan kebijakan di Kantor Pelayanan Pajak itu sendiri.
\end{abstract}

Kata Kunci : Penerapan Kebijakan, e-Faktur, Pelayanan Wajib Pajak

\begin{abstract}
Tax is one of the important components of the State administration because of all activities that enter the State treasury. Based on this it becomes very important how the Directorate of Tax Jederal as a state institution in charge of taxation can create policies that can maximize tax revenue for the country. And one of the policies made by the Directorate General of Taxes is an electronic Tax Invoice referred to as an e-invoice which was officially launched on 1 July 2014. The emergence of the policy is based on the abundance of tax invoices in the form of fictitious taxes with a high number of violations. The purpose of this study is to determine the implementation of Electronic Tax Invoice policy in order to ease service to taxpayers at the tax service office pratama South Bekasi.This type of research used in this research is descriptive by using qualitative approach.The results showed that the Application of Electronic Tax Invoice Policy In A Framework of Ease to Taxpayers at the Office Pratama South Bekasi Overall quite good although there are still some that hamper in the manufacture of tax invoices and affect taxpayer compliance such as uneven socialization conducted by the tax service office,Servers are often down / offline,An unstable Internet network, Knowledge of taxable companies that are still less policy-related and the lack of members of the tax authorities to socialize the policy in the Tax Office itself.
\end{abstract}

Keywords: Implementation of policies,E-Faktur,Taxpayer Services PENDAHULUAN 
Mega Kusuma dan Nopikah Safitri, Penerapan Kebijakan Elektronik Faktur Pajak...

Faktur Pajak merupakan bukti pungutan pajak yang dibuat oleh Pengusaha Kena Pajak karena penyerahan Barang Kena Pajak atau penyerahan Jasa kena Pajak atau bukti pungutan pajak karena impor Barang kena pajak yang digunakan oleh Direktorat Jenderal Bea dan Cukai (Waluyo, 2011:315). Faktur pajak berfungsi sebagai bukti pungutan pajak dan dapat digunakan sebagai sarana untuk mengkreditkan Pajak Masukan. Berkembanganya perdagangan di Indonesia terutama yang berkaitan dengan ekspor impor meningkatkan penerimaan pajak yang didapat dari faktur pajak, umumnya perusahaan yang berorientasi ekspor tidak perlu melakukan pemungutan PPN, hal ini dimaksudkan untuk meningkatkan perdagangan yang lebih kompetitif di luar negeri. Namun kemudahan fasilitas perpajakan yang diberikan pemerintah justru dimanfaatkan secara tidak benar oleh wajib pajak nakal untuk membobol kas negara. Modus yang dilakukan oknum nakal ini beragam mulai dari mark up nilai pajak agar mendapat restitusi lebih besar, sampai pemalsuan faktur pajak yang digunakan untuk ekspor fiktif. Faktur pajak palsu yang digunakan ini, biasa disebut pajak tidak sah/bermaslah/fiktif. Melihat kondisi seperti ini tentu akan sangat merugikan negara.Tahun 2010, Penyelidik Direktorat Jenderal Pajak menginvestigasi kerugian negara sebesar Rp 607 milyar yang disebabkan oleh penyalahgunaan faktur pajak fiktif. Dan dalam berita pada tahun 2009 hingga 2012 kerugian Negara akibat Faktur Pajak Fiktif mencapai Rp 1,1 Triliun. Faktur Pajak fiktif secara sederhana merupakan faktur pajak yang tidak sah, misalnya karena identitas Pengusaha Kena Pajak (PKP) penerbit tidak sesuai dengan keadaan yang sebenarnya (Luiyanto dan Titi Muswati, 2009). Penyalahgunaan faktur pajak fiktif ini bukan hanya melibatkan PKP semata melainkan juga oknum petugas pajak, serta pihak-pihak lainya yang berhasil diungkap oleh aparat hukum yang berwenang. Meskipun oknum yang terkait dengan penyalahgunaan faktur pajak fiktif tersebut sudah dijatuhi hukuman, ternyata efek jera yang ditimbulkan tidak berpengaruh. Dengan kata lain permasalahan ini masih terus saja terjadi. Melihat banyaknya kasus penyalahgunaan faktur pajak fiktif membuat pemerintah mencari cara yang efektif untuk menanggulanginya, dan mulai tahun 2013 ini Direktorat Jenderal Pajak menerapkan kebijakan baru yang tertuang dalam peraturan PER-24/PJ/2012 sebagai penyempurna peraturan PER-13/PJ/2010, poin terpenting dalam peraturan baru ini mengenai perubahan penomoran seri Faktur Pajak dimana dalam PER-24/PJ/2012 penomoran seri faktur pajak tidak dilakukan sendiri oleh PKP melainkan dilakukan oleh Direktorat Jenderal Pajak. Tidak semua PKP akan diberikan jatah nomor faktur pajak, Kantor Pelayanan Pajak akan lebih selektif dalam memberikan nomor pajak, hanya pengusaha yang dianggap layak dan diyakini keberadaanya diberikan nomor faktur pajak, yaitu mereka yang telah melakukan kegiatan verifikasi dan registrasi ulang. Perubahan kebijakan baru mengenai penomoran seri faktur pajak yang tertuang dalam PER-24/PJ/2012, bertujuan untuk meminimalkan peyalahgunaan faktur pajak oleh oknum yang tidak bertanggung jawab, dimana mekanisme pelaksanaan lebih diperketat, sehingga diharapkan penerimaan kas negara dari faktur pajak bisa terserap dengan maksimal. Perubahan tentunya bertujuan untuk perubahan yang lebih baik, hanya saja jika sosialisasi yang dilakukan Dirjen Pajak tidak mengenai sasaran tentu akan menimbulkan masalah lain, dimana masyarakat kita cenderung mencari sesuatu yang mudah.Dengan adanya kebijakan baru ini tentu juga akan menambah pekerjaan bagi fiskus pajak dalam memberikan pelayanan. Sistem perpajakan tetntunya juga harus di update sedemikan rupa agar mampu memberikan pelayanan yang maksmimal kepada masyarakat. Terutama untuk sistem elektronik SPT atau yang biasa dikenal dengan e-SPT. Jangan sampai sistem yang digunakan ini belum terupdate sehingga ada layanan yang tidak bisa diakses oleh PKP dalam penyampaian faktur pajak PPN. Dengan kebijakan baru ini bukan hanya 
Jurnal Ilmiah Untuk Mewujudkan Masyarakat Madani ISSN 2355-309X

menambah pekerjaan bagi fiskus pajak dalam memberikan layanan, melainkan juga PKP itu sendiri yang tentunya akan menyita lebih banyak waktu karena harus bolak-balik ke Kantor Pelayanan Pajak, belum lagi harus ada legalisasi dari pejabat yang berwenang dalam penanda- tanganan faktur pajak. Bagi PKP tentu dirasa akan sangat kurang efisien dan efektif.

penelitian deskriptif dengan pendekatan kualitatif. Hasil ini adalah penerapan sistem elektronik nomor faktur di KPP Pratama Cikarang Utara ini belum sepenuhnya mampu mencegah faktur pajak fiktif terutama untuk faktur pajak yang diterbitkan bukan berdasarkan transaksi yang sebenarnya karena setelah penerapan e-nofa ini masih ada kasus faktur pajak fiktif di KPP Pratama Cikarang Utara, namun mampu mencegah penerbitan faktur pajak fiktif yang diterbitkan bukan oleh PKP. Hambatan yang muncul adalah sulit menyesuaikan sistem di perusahaan milik PKP, masih harus datang ke KPP, ketergantungan sistem dan jaringan internet, sinkronisasi data KPP dengan DJP. Alternatif cara mengatasi hambatan tersebut yang dilakukan oleh KPP Pratama Cikarang Utara adalah dengan melakukan sosialisasi dan menindaklanjuti kendala yang ada, E-NOFA Online, meningkatkan kualitas sistem dan jaringan internet, dan restart server admin. Reformasi perpajakan di sektor Pajak Pertambahan Nilai (PPN) dilakukan pemerintah untuk memaksimalkan penerimaan negara di sektor perpajakan dengan melakukan, karena Pajak Pertambahan Nilai penyumbang penerimaan negara di sektor perpajakan terbesar kedua setelah Pajak Penghasilan (Badan Pusat Statistik :2015). Pemerintah melakukan Reformasi perpajakan dengan menerapkan sistem Elektronik Nomor Faktur sebagai salah satu bentuk modernisasi perpajakan. Penomoran faktur pajak yang semula dibuat oleh Pengusaha Kena Pajak sendiri, setelah adanya Peraturan Direktur Jenderal Pajak Nomor PER-24/PJ/2012 tentang Bentuk, Ukuran , Tata Cara Pengisian Keterangan, Prosedur Pemberitahuan Dalam Rangka Pembuatan, Tata Cara Pembetulan atau
Penggantian dan Tatat Cara Pembatalan Faktur Pajak penomoran faktur pajak diubah menjadi E-NOFA (Elektronik Nomor Faktur) Pajak. E-NOFA diciptakan untuk mencegah penerbitan faktur pajak fiktif, dengan sistem baru ini di harapkan mampu mengurangi praktik kecurangan yang dilakukan oleh pengusaha kena pajak yang dapat merugikan negara. Kasus penerbitan faktur pajak fiktif mencapai 100 kasus pada tahun 2010 hingga 2013, hal tersebut dapat merugikan negara karena kerugian negara yang disebabkan faktur pajak fiktif ini sekitar 1,5 Triliun (Widodo dan Widyadnyana : 2015). Maraknya faktur pajak fiktif yang dilakukan oleh pihak-pihak yang tidak bertanggung jawab maka pemerintah mengharapkan penerapan e-NOFA dapat mencegah penerbitan faktur pajak fiktif (Direktur Jenderal Pajak :2013). Pajak merupakan sumber utama penerimaan negara. Tanpa pajak, sebagian besar kegiatan Negara sulit untuk dapat dilaksanakan. Di Negara ini juga terdapat begitu banyak jenis pajak yang tentu saja hal ini dapat menambah pendapatan Negara dan dengan begitu banyak jenis pajak yang ada di Indonesia, salah satunya adalah Pajak Pertambahan Nilai yang merupakan salah satu pajak yang menyumbangkan pendapatan Negara yang bisa dikatakan besar bagi Negara.

Pajak Pertambahan Nilai termasuk jenis pajak tidak langsung, maksudnya pajak tersebut disetor oleh pihak lain (pedagang) yang bukan penanggung pajak atau dengan kata lain, penanggung pajak (konsumen akhir) tidak menyetorkan langsung pajak yang ditanggung. Mekanisme pemungutan, penyetoran, dan pelaporan PPN ada pada pihak pedagang atau produsen sehingga muncul istilah Pengusaha Kena Pajak yang disingkat PKP. Dalam penghitungan PPN yang harus disetor oleh PKP, dikenal istilah pajak keluaran dan pajak masukan. Pajak Masukan merupakan Pajak Pertambahan Nilai yang seharusnya sudah dibayar Pengusaha Kena Pajak (PKP) karena perolehan Barang Kena Pajak (BKP) atau Jasa Kena Pajak (JKP) di dalam daerah pabean dan atau pemanfaatan BKP tidak berwujud dari luar 
Mega Kusuma dan Nopikah Safitri, Penerapan Kebijakan Elektronik Faktur Pajak...

daerah pabean dan atau pemanfaatan JKP dari luar daerah pabean. Sedangkan Pajak Keluaran adalah Pajak Pertambahan Nilai yang terutang yang wajib dipungut oleh Pengusaha Kena Pajak yang melakukan penyerahan Barang Kena Pajak, penyerahan Jasa Kena Pajak atau ekspor Barang Kena Pajak.

\section{TINJAUAN PUSTAKA}

Tinjauan pustaka pada penelitian mengambil referensi dari buku-buku serta mencari referensi lain yang dianggap bisa dijadikan acuan penelitian ini seperti situs internet dan berkonsultasi dengan narasumber yang lebih berpengalaman. Adapun kajian pustaka pada penelitian ini meliputi konsep mengenai penerapan e-Faktur Pajak dalam rangka kemudahan pelayanan kepada wajib pajak.

\section{(a). Pengertian pajak}

Ditinjau dari jumlah pendapatan yang diterima oleh negara, penerimaan pajak merupakan penerimaan yang dominan dari seluruh penerimaan negara. Banyak para ahli memberikan batasan tentang pajak, tetapi pada intinya mempunyai maksud dan tujuan yang sama. Berikut ini adalah beberapa pengertian mengenai pajak oleh para ahli, yaitu: Banyak para ahli memberikan batasan tentang pajak, diantaranya pengertian pajak yang dikemukakan oleh R. Santoso Brotodiharjo, pajak adalah peralihan kekayaan dari pihak rakyat kepada kas negara untuk membiayai pengeluaran rutin dan surplusnya digunakan untuk public saving yang merupakan sumber utama untuk membiayai public investment. Menurut Waluyo (2009:2) pengertian pajak adalah sebagai berikut: "Pajak adalah iuran masyarakat kepada negara (yang dapat dipaksakan) yang terutang oleh yang wajib membayarnya menurut peraturan-peraturan umum (undang-undang) dengan tidak mendapat prestasi kembali yang langsung dapat ditunjuk dan yang gunanya adalah untuk membiayai pengeluaran-pengeluaran umum berhubung tugas negara untuk menyelenggarakan pemerintahan". Pengertian pajak berdasarkan Pasal 1 UU No. 28 Tahun 2007 tentang ketentuan umum dan tata cara perpajakan adalah sebagai berikut; "Pajak adalah kontribusi wajib pada negara yang terutang oleh orang pribadi atau badan yang bersifat memaksa berdasarkan undangundang, dengan tidak mendapatkan imbalan secara langsung dan digunakan untuk keperluan negara bagi sebesar-besarnya kemakmuran rakyat". Tentang perpajakan ada beberapa pendapat dari para ahli yang dikutip dari Siti Resmi (2009), antara lain: Menurut Rochmat Soemitro: "Pajak adalah iuran rakyat kepada kas neara berdasarkan undang-undang (yang dapat dipaksakan) dengan tidak mendapat jasa timbal balik yang langsung dapat ditunjukkan dan yang digunakan untuk membayar pengeluaran umum". Pengertian tersebut disempurnakan menjadi, pajak adalah peralihan kekayaan dari pihak rakyat kepada kas negara untuk membiayai pengeluaran rutin dan "surplus"nya digunakan untuk public saving yang merupakan sumber utama untuk membiayai public investment. Menurut S. I. Djajadiningrat: "Pajak sebagai suatu kewajiban menyerahkan sebagian dari kekayaan ke kas negara yang disebabkan suatu keadaan, kejadian dan perbuatan yang memberikan kedudukan tertentu, tetapi bukan sebagai hukuman, menurut peraturan yang ditetapkan pemerintah serta dapat dipaksakan tetapi tidak ada jasa timbal balik dari negara secara langsung untuk memelihara kesejahteraan umum". Menurut N. J. Feldmann: "Pajak adalah prestasi yang dipaksakan sepihak oleh dan terutang kepada penguasa (menurut norma-norma yang ditetapkannya secara umum), tanpa adanya kontraprestasi dan semata-mata digunakan untuk menutupi pengeluaran-pengeluaran umum". Berdasarkan pengertian di atas dapat dirumuskan bahwa administrasi adalah suatu proses pengolahan data dengan suatu perencanaan sampai dengan tujuan yang hendak dicapai. untuk menentukan besarnya pajak terutang berada pada fiskus, Wajib Pajak bersifat pasif, utang pajak timbul 
Jurnal Ilmiah Untuk Mewujudkan Masyarakat Madani ISSN 2355-309X

setelah dikeluarkan surat ketetapan pajak oleh fiskus.

\section{Sistem Pemungutan Pajak}

Dalam pemungutan pajak dikenal beberapa sistem yang digunakan di Indonesia. Berikut sistem pemungutan pajak menurut Thomas Sumarsan (2014: 6), yaitu :

1) Official Assessment System

Adalah sistem pemungutan pajak yang memberi wewenang kepada pemerintah (fiskus) untuk menentukan besarnya pajak yang terutang. Ciri - ciri Official Assessment System :wewenang

\section{2) Self Assessment System}

Adalah sistem pemungutan pajak yang memberi wewenang, kepercayaan, tanggung jawab kepada Wajib Pajak untuk menghitung, memperhitungkan, membayar, dan melaporkan sendiri besarnya pajak yang harus dibayar.Fiskus hanya mengawasi.

3) Withholding Tax System

Adalah sistem pemungutan pajak yang memberi wewenang kepada pihak ketiga untuk memotong atau memungut besarnya pajak yang terutang oleh Wajib Pajak.

\section{1) Kualitas Pelayanan}

Suatu tindakan atau perbuatan yang ditawarkan suatu pihak kepada pihak lain yang dapat menciptakan nilai dan memberikan manfaat kepada pelanggan pada waktu dan tempat tertentu dengan menimbulkan perubahan keinginan atau kepentingan peneriman layanan. (Lovelock dan Writz : 2004)

\section{2) Pengertian Pelayanan}

Dalam Kamus Besar Bahasa Indonesia dijelaskan pelayanan adalah suatu kegiatan atau urutan kegiatan yang terjadi dalam interaksi langsung antara seseorang dengan orang lain atau mesin secara fisik, dan menyediakan kepuasan pelanggan. Pengertian Pelayanan yang ditulis Kotler yang dialih Bahasa oleh Aleksander Sindoro (2004:58) adalah Sebagai berikut : "Pelayanan sebagai suatu tindakan atau kinerja yang ditawarkan oleh suatu pihak kepada pihak lain dan pada dasarnya tidak berwujud dan tidak mengakibatkan kepemilikan apapun. Produknya dapat berupa fisik dan non fisik." Melalui Surat Edaran Direktur Jenderal Pajak

No. SE-45/PJ/2007 ditegaskan mengenai pelayanan perpajakan : "Pelayanan adalah sentra dan indikator utama untuk membangun citra DJP, sehingga kualitas pelayanan harus terus menerus ditingkatkan dalam rangka mewujudkan harapan dan membangun kepercayaan Wajib Pajak terhadap DJP.”

\section{Pengertian Kualitas Pelayanan}

Definisi Kualitas Pelayanan Yang ditulis Lewis dan Baums yang dikutip oleh Lena Ellitan dan Lina Anatan (2007:47) adalah Sebagai berikut: "Kualitas layanan merupakan sebagai ukuran seberapa bagus tingkat layanan yang diberikan mampu menyesuaikan dengan ekspentasi pelanggan, jadi kualitas pelayanan diwujudkan melalui pemenuhan kebutuhan dan keinginan pelanggan serta ketetapan penyampaian pelayanan tersebut membagi harapan pelanggan." Dan Menurut Barta (2004, 205273) dalam kualitas pelayanan harus memberikan pelayanan yang prima dimana Menurut Barata (2004, 205-273) terdapat tiga konsep yang harus dijalankan oleh pihak yang melayani dalam memberikan pelayanan yang prima yaitu :

1.Pelayanan prima berdasarkan konsep dan sikap (attitude) yaitu suatu layanan kepada pelanggan dengan menonjolkan sikap yang baik dan menarik antara lain melayani pelanggan dengan penampilan serasi, berpikiran positif dan dengan sikap menghargai pelanggan. 2. Pelayanan prima berdasarkan konsep perhatian (attention) yaitu suatu layanan kepada pelanggan. 3. Pelayanan prima berdasarkan konsep tindakan (Action) yaitu serangkaian perbuatan nyata yang dilakukan untuk mewujudkan pemberian layanan yang terbaik bagi pelanggan. Maka dari tiga konsep pelayanan tersebut dapat ditarik simpulan bahwa sikap (attitude) dan perhatian (attention) dalam melakukan pelayanan yang baik adalah dasar bagi pemberi layanan memberikan pelayanan yang secara nyata akan terwujud menjadi suatu kesatuan bentuk pelayanan yang baik ketika melakukan berbagai tindakan (action) terbaik 
Mega Kusuma dan Nopikah Safitri, Penerapan Kebijakan Elektronik Faktur Pajak...

untuk melayani pelanggan. (Barata 2004, 205273).

\section{Faktur Pajak}

Menurut Siti Resmi (2015: 48-49) menjelaskan bahwa faktur pajak adalah:

"Faktur Pajak adalah bukti pungutan pajak yang dibuat oleh PKP yang melakukan penyerahan Barang Kena Pajak atau penyerahan Jasa Kena Pajak".Faktur pajak mempunyai fungsi sebagai berikut:

1) Sebagai bukti pungut PPN yang dibuat oleh PKP atau Direktorat Jenderal Bea dan Cukai, baik karena penyerahan BKP atau JKP maupun impor BKP.

2) Sebagai bukti pembayaran PPN yang telah dilakukan oleh pembeli BKP atau penerima JKP kepada PKP atau Direktorat Bea dan Cukai.

3) Sebagai sarana pengawasan administrasi terhadap kewajiban perpajakan.

Faktur pajak baru mencantumkan keterangan sebagai berikut:

1) Nama, alamat, nomor pkok wajib pajak yang menyerahkan BKP atau JKP;

2) Nama, alamat, nomor pkok wajib pajak pembeli BKP atau penerima JKP;

3) Jenis barang atau jasa, jumlah harga jual atau penggantian, dan potongan harga;

4) Pajak Pertambahan Nilai yang dipungut;

5) Pajak penjualan atas barang mewah yang dipungut;

6) Kode, nomor seri, dan tanggal pembuatan faktur pajak;

7) Nama dan tanda tangan yang berhal menandatangani faktur pajak.

Faktur pajak merupakan bukti pemungutan bukti pemungutan pajak dan dapat digunakan sebagai sarana untuk mengkreditkan Pajak Masukan. Oleh karena itu, faktur pajak harus benar, baik secara formal maupun secara materiil. Faktur pajak harus diisi secara lengkap, jelas, benar dan ditandatangani oleh pejabat yang ditunjuk PKP untuk menandatanganinya. Faktur pajak yang tidak diisi sesuai dengan ketentuan ini dapat mengakibatkan PPN yang tercantum didalamnya tidak dapat dikreditkan.PKP diwajibkan membuat faktur pajak untuk setiap penyerahan BKP atau JKP. Namun, untuk meringankan beban adminsitrasi, kepada PKP diperkenankan membuat satu faktur pajak yang meliputi semua penyerahan BKP atau JKP yang terjadi selama satu bulan takwim kepada pembeli BKP yang sama atau penerima JKP yang sama. Faktur pajak yang demikian disebut Faktur Pajak Gabungan. Faktur Pajak Gabungan dibuat paling lambat pada akhir bulan penyerahan BKP dan/atau JKP meskipun dalam bulan penyerahan telah terjadi pembayaran sebagian atau seluruhnya.

\section{a) Jenis Faktur Pajak}

Berdasarkan Pasal 13 ayat (2) UU PPN 2009, PKP dapat membuat 1 (satu) Faktur Pajak meliputi seluruh penyerahan yang dilakukan kepada pembeli BKP atau semua penerima JKP yang sama selama 1 (satu) bulan kalender. Dalam memori penjelasannya ditegaskan bahwa Faktur Pajak yang seperti ini dinamakan Faktur Pajak Gabungan. Faktur Pajak Gabungan tidak diperlakukan sebagai satu jenis Faktur Pajak tersendiri sebagai jenis keempat karena Faktur Pajak ini bentuknya tidak berbeda. Hal yang membedakan hanya fungsinya yaitu satu faktur pajak dipergunakan untuk seluruh penyerahan BKP atau JKP dalam satu Masa Pajak untuk pembeli BKP atau penerima JKP yang sama. Faktur Pajak khusus adalah Faktur Pajak yang dibuat oleh PKP Retail tertentu yang melakukan penyerahan BKP kepada orang pribadi pemegang paspor luar negeri, sebagaimana ditentukan dalam Peraturan Menteri Keuangan Nomor 76/PMK.03/2010 tanggal 31 Maret 2010.

\section{b) Pengusaha Kena Pajak}

Menurut UU No. 42 Tahun 2009 Pasal 3A ayat 1, Pengusaha Kena Pajak adalah Pengusaha yang melakukan penyerah Barang Kena Pajak dan/atau penyerahan Jasa Kena Pajak di dalam Daerah, Pabean dan/atau melakukan ekspor Barang Kena Pajak Tidak Berwujud diwajibkan:

1) Melaporkan usahanya untuk dikukuhkan sebagai Pengusaha Kena Pajak

2) Memungut pajak terutang 
Jurnal Ilmiah Untuk Mewujudkan Masyarakat Madani ISSN 2355-309X

3) Menyetorkan Pajak Pertambahan Nilai yang masih harus dibayar dalam hal Pajak Keluaran lebih daripada Pajak Penjualan atas Barang Mewah yang terutang, dan

4) Melaporkan perhitungan pajak. Kewajiban diatas tidak berlaku untuk

pengusaha kecil yang batasannya ditetapkan oleh Menteri Keuangan Pengusaha yang dikecualikan dari kewajiban sebagai Pengusaha Kena Pajak adalah pengusah kecil dan pengusaha yang semata-mata menyerahkan barang atau jasa yang tidak dikenakan PPN. Pengusaha Kecil adalah pengusaha yang selama satau tahun buku melakukan penyerahan BKP dan/atau JKP dengan jumlah peredaran bruto dan/atau penerimaan bruto tidak lebih dari $\mathrm{Rp}$ 600.000.000. pengusaha kecil wajib melaporkan usahanya untuk dikukuhkan sebagaiPKP, apabila sampai dengan satu bulan dalam tahun buku, jumlah peredaran bruto dan/atau penerimaan brutonya melebihi batas yang ditetapkan. Pengusaha tersebut wajib melaporkan usahanya untuk dikukuhkan sebagai PKP paling lambar pada akhir bulan berikutnya. Beberapa hal yang perlu diketahui sehubungan dengan pengusaha kecil:

1) Dilarang membuat faktur pajak

2) Tidak wajib memasukkan SPT Masa PPN

3) Diwajibkan membuat pembukuan atau pencatatan

4) Wajib melapor untuk dikukuhkan sebagai PKP, bagi pengusaha kecil yang memperoleh peredaran bruto diatas batas yang telah ditentukan (Mardiasmo, 2008:278).

\section{Kebijakan Peraturan Elektronik Faktur Pajak yaitu :}

Peraturan Penerapan E-Faktur Menurut Peraturan Direktur Jenderal Pajak Nomor PER-16/PJ/2014 disebutkan bahwa Faktur Pajak berbentuk elektronik, yang selanjutnya disebut e-Faktur, adalah Faktur Pajak yang dibuat melalui aplikasi atau system elektronik yang ditentukan dan/atau disediakan oleh Direktorat Jenderal Pajak. Berdasarkan uraian diatas dapat disimpulkan bahwa faktur pajak yang berbentuk elektronik di buat melalui sistem elektronik yang disediakan oleh Direktorat Jenderal Pajak.

\section{Dasar Hukum}

Salah satu Dasar Hukum yang mengatur tentang e-Faktur adalah Peraturan Direktur Jenderal Pajak Nomor PER-16/PJ/2014 tentang Tata Cara Pembuatan dan Pelaporan Faktur Pajak Berbentuk Elektronik.

\section{Jenis Faktur Pajak}

Berdasarkan Pasal 13 ayat (2) UU PPN 2009, PKP dapat membuat 1 (satu) Faktur Pajak meliputi seluruh penyerahan yang dilakukan kepada pembeli BKP atau semua penerima JKP yang sama selama 1 (satu) bulan kalender. Dalam memori penjelasannya ditegaskan bahwa Faktur Pajak yang seperti ini dinamakan Faktur Pajak Gabungan. Faktur Pajak Gabungan tidak diperlakukan sebagai satu jenis Faktur Pajak tersendiri sebagai jenis keempat karena Faktur Pajak ini bentuknya tidak berbeda. Hal yang membedakan hanya fungsinya yaitu satu faktur pajak dipergunakan untuk seluruh penyerahan BKP atau JKP dalam satu Masa Pajak untuk pembeli BKP atau penerima JKP yang sama.Faktur Pajak khusus adalah Faktur Pajak yang dibuat oleh PKP Retail tertentu yang melakukan penyerahan BKP kepada orang pribadi pemegang paspor luar negeri, sebagaimana ditentukan dalam Peraturan Menteri Keuangan Nomor 76/PMK.03/2010 tanggal 31 Maret 2010.

\section{PKP yang wajib membuat e-faktur}

PKP yang diwajibkan membuat Faktur Elektronik adalah PKP yang telah ditetapkan dengan Keputusan Direktur

Jenderal Pajak. (Pasal 1 ayat (2) PER16/PJ/2014):

a. Daftar PKP yang waib membuat E-Faktur mulai tanggal 1 Juli 2014: (diktum pertama KEP-136/PJ/2014).

b. Daftar PKP yang wajib membuat E-Faktur mulai tanggal 1 Juli 2015: (diktum kedua KEP-136/PJ/2014). 
Mega Kusuma dan Nopikah Safitri, Penerapan Kebijakan Elektronik Faktur Pajak...

c. PKP yang wajib membuat E-Faktur mulai tanggal 1 Juli 2016: (diktum ketiga KEP136/PJ/2014) yaitu:

1. PKP selain PKP yang ada di Lampiran I dan II KEP-136/PJ/2014, dan

2. PKP selain PKP yang diwajibkan membuat Faktur Pajak berebntuk elektronik selain yang telah ditetapkan dalam KEP-136/PJ/2014.

d. PKP yang wajib membuat E-Faktur mulai tanggal PKP dikukuhkan:(diktum keempat KEP-136/PJ/2014) yaitu PKP yang dikukuhkan setelah tanggal 1 Juli 2016.

1. Dalam hal PKP sebagaimana diatur pada Diktum Pertama, Diktum Kedua, dan Diktum Kedelapan berpindah tempat pengukuhan PKP-nya, kewajiban untuk membuat Faktur Pajak berbentuk elektronik tetap berlaku. (dictum keenam KEP136/PJ/2014).

2. PKP yang telah diwajibkan membuat Faktur Pajak berbentuk elektronik namun tidak membuat Faktur Pajak berbentuk elektronik namun tidak mengikuti tata cara sebagaimana dimaksud pada PER-16/PJ/2014, PKP tersebut dianggap tidak membuat Faktur Pajak. (Pasal 11 ayat (4) PMK151/PMK.03/2013).

\section{Sanksi atas tidak menerapkan aplikasi e- faktur}

Menurut Direktorat Jenderal Pajak (DJP) Kementerian Keuangan (Kemenkeu) yang dikutip dari website www.pajak.go.id, bakal mengenakan sanksi sebesar 2\% Persen dari Dasar Pengenaan Pajak (DPP) kepeda Pengusaha Kena Pajak (PKP) di Jawa dan Bali yang belum menggunakan Faktur Elektronik mulai 1 Juli. Sanksi tersebut diatur dalam Pengumuman Direktur Jenderal (Dirjen) Pajak Nomor Peng-6/RJ.02/2015 tentang Penegasan atas Faktur Elektronik tertanggal 16 Juni 2015. Pengumuman tersebut sebagai penegasan kembali atas Peraturan Menteri Keuangan (PMK) Nomor 151/PMK.03/2013 tentang Tata Cara Pembetulan dan Penggantian Faktur Pajak, sekaligus penegasan atas Keputusan Dirjen Pajak Nomor: KEP-136/PJ/2014 tentang Penetapan Pengusaha Kena Pajak yang diwajibkan Membuat Faktur Pajak Berbentuk Elektronik.

\section{Kerangka Pemikiran}

Kerangka pemikiran dalam penelitian dapat dijabarkan sebagai berikut, e-faktur merupakan salah satu sistem administrasi perpajakan yang mengalami reformasi dari Faktur Pajak yang tadinya manual digantikan dengan Faktur Pajak Elektronik, yang dalam pengoperasiannya menggunakan perangkat komputer dan dapat terkoneksi melalui jaringan internet. Modernisasi administrasi perpajakan yang dilakukan lembaga pemerintah yaitu Direktorat Jenderal Pajak (DJP) dalam mengeluarkan kebijakan baru tentunya tidak hanya bertujuan untuk memberikan kemudahan bagi Pengusaha Kena Pajak (PKP) dalam membuat Faktur Pajak. Dengan menggunakan dan memanfaatkan teknologi elektronik, seperti tanda tangan dengan menggunakan tinta basah digantikan dengan menggunakan tanda tangan elektronik, serta elektronik faktur pajak tidak harus dicetak karena bisa di simpan dalam bentuk file PDF.

Dengan adanya e-faktur diharapkan adanya pencapaian target penerimaan negara dari sektor pajak. Kemudahan lain dengan adanya kebijakan tersebut dalam melakukan administrasi perpajakan yaitu, dalam hal prosedur kegiatan penyelenggaraan pemungutan pajak dengan menggunakan aplikasi Faktur Elektronik menjadi kesatuan dengan aplikasi e-SPT yang dapat memudahkan Wajib Pajak dalam pelaporan Surat Pemberitahuan (SPT) masa PPN. Serta permintaan Nomor Seri Faktur Pajaknya sendiri disediakan secara online, sehingga Wajib Pajak tidak perlu lagi datang ke Kantor Pelayanan Pajak. Sementara bagi Direktorat Jenderal Pajak berharap dengan adanya peraturan tersebut dapat meningkatkan validitas E-faktur diharapkan akan meminimalisir Faktur Pajak fiktif sehingga 
Jurnal Ilmiah Untuk Mewujudkan Masyarakat Madani

ISSN 2355-309X

akan memudahkan pengawasan dan pelayanan kepada Wajib Pajak.

Dalam hal implementasi kebijakan Faktur Elektronik pajak peneliti menerapkan

4 (empat) komponen yaitu, Komunikasi, Sumber Daya, Disposisi, dan Struktur Birokasi. Implementasi sangat penting dilakukan untuk merealisasikan kebijakan yang dikeluarkan Direktorat Jenderal Pajak agar tujuan yang diharapkan tercapai dalam hal meningkatkan kepatuhan Wajib Pajak dan meningkatkan penerimaan pajak dari sektor Pajak Pertambahan Nilai. Dalam hal ini lebih difokuskan kepada kepatuhan Wajib Pajak pada Kantor Pelayanan Pajak Pratama Dua Bekasi Selatan tahun 2015-2016.

Dalam uraian di atas menuangkan kerangka konseptual dalam bentuk model konseptual sebagai berikut :

\section{Gambar 1.1}

Model Konseptual

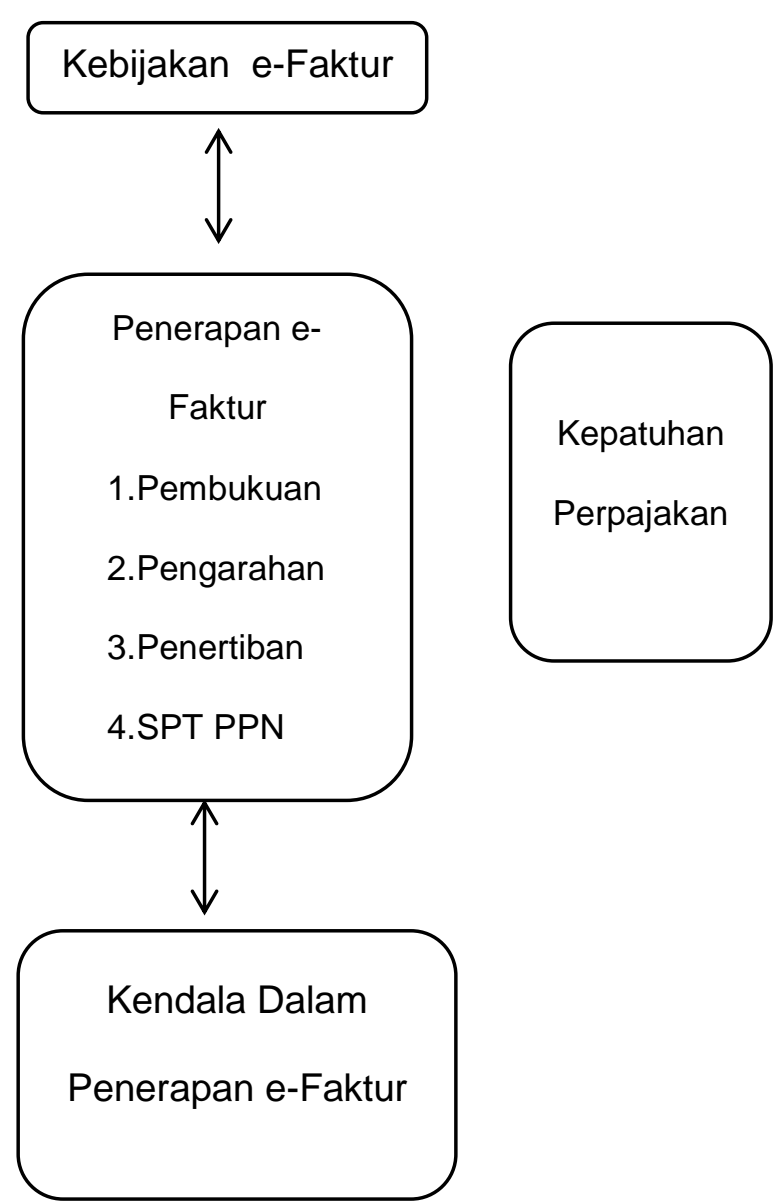

\section{PEMBAHASAN}

Penerapan kebijakan e-faktur dalam rangka kemudahan pelayanan kepada wajib pajak pada KPP Pratama Bekasi Selatan

Diberlakukannya Penerapan Kebijakan eFaktur karena memperhatikan masih terdapat penyalahgunaan faktur pajak, diantaranya Wajib Pajak Non PKP yang menerbitkan faktur pajak padahal tidak berhak menerbitkan faktur pajak, faktur pajak ganda. Juga karena beban administrasi yang begitu besar bagi pihak DJP maupun bagi PKP, dan tujuan lain dari dikeluarkannya kebijakan ini yaitu untuk mempermudah administrasi dari faktur pajak dalam hal ini untuk memonitoring kembali kebenaran dari faktur masukan dan faktur pajak keluaran secara sistem elektronik.

Kendala-Kenndala yang dihadapi oleh KPP Bekasi Selatan dalam memberikan pelayanan dan pengawasan terkait dengan kebijakan E-faktur.

Kendala yang dihadapi untuk penerapan kebijak e-faktur adalah tidak meratanya sosialisasi,server yang sering down, jaringan internet yang kurang stabil, Pengetahuan PKP yang masih kuran paham dan kurangnya anggota fiskus Account Representative untuk mengawasi. Dalam hubungannya dengan uraian tersebut di atas dikatakan bahwa penerapan kebijakan e-Faktur yang dilakukan selama ini di KPP Pratama Bekasi Selatan sudah cukup mempermudah PKP tetapi evaluasi pada suatu kebijakan, dalam meningkatkan kepatuhan wajib pajak di KPP Pratama Bekasi Selatan diantaranya Komunikasi sangat penting demi tercapainya pemahaman suatu kebijakan yang disampaikan oleh KPP Pratama Bekasi Selatan kepada wajib pajak. Sosialisasi merupakan salah satubentuk komunikasi dimana semua informasi mengenai kebijakan e-Faktur akan disampaikan secara langsung

oleh fiskus hal ini seperti diadakannya sosialisasi dalam bentuk penyuluhan yang di adakan pada awal tahun 2015 yang bertempatan di KPP Pratama Bekasi Selatan 
Mega Kusuma dan Nopikah Safitri, Penerapan Kebijakan Elektronik Faktur Pajak...

tentang kebijkan e-Faktur kepada seluruh wajib pajak yang utama Pengusaha Kena Pajak (PKP).

\section{KESIMPULAN}

Dalam Rangka Kemudahan Pelayanan Kepad wajib Pajak Pada Kantor Pelayanan Pajak Pratama Bekasi Selatan dapat ditarik kesimpulan sebagai berikut :

1. Penerapan Kebijakan Faktur Pajak Elektronik di Kantor Pelayanan Pajak pratama Bekasi Selatan. Kebijakan ini sangat membantu dan mempermudah PKP dalam melakukan administrasi, pelaporan, dan waktu dalam melaksanakan kewajiban perpajakannya karena menyederhanakan prosedur serta dapat mencegah kecurangan dalam perpajakan seperti faktur pajak fiktif. Penerapan Kebijakan Faktur Pajak Elektronik di KPP Pratama Bekasi Selatan pada wajib pajak atau PKP sudah sesuai dengan aturan perpajakan.

2. Kendala dalam penerapan kebijakan faktur pajak elektronik bisa tidak

meratanya sosialisasi yang dilakukan DJP/KPP, wajib pajak yang belum sepenuhnya mengerti cara mengunakan dan menerapkan kebijakan faktur pajak elektronik, dan dikarenakan oleh server DJP yang sering down/offline, jaringan internet tidak memadai atau tidak stabil dan kurangnya SDM di KPP sebagai Account Representative yang melalukan pengawasan terhadap PKP yang tidak patuh.

\section{DAFTAR PUSTAKA}

Adya Atep Barata. 2015. Dasar-dasar Pelayanan Prima, Cetakan 2.Jakarta. PT Elexmedia Komputindo
Anatan,Lina, Elitan Lena 2016. Manajemen Sumber Daya Manusia dalam Bisnis Modern. Penerbit Alfabeta

Kurniawan Ary.2015. Penerapan E-Faktur Pajak terhadap Pengusaha Kena Pajak diKota Surabaya Laporan Penelitian Fakultas Ekonomi Universitas Airlangga

Philip Kotler, Gary Amstrong:Ahli Bahasa Alexander Sindoro.2004, Dasar-dasar Pemasaran edisi Kesembilan, Jilid 2, Jakarta :Penerbit PT Index.

Pohan, Chairil Anwar Drs.2016. Pedoman Lengkap Pajak Pertambahan Nilai.Teori Konsep, dan Aplikasi PPN. PT. Gava medi.Yogyakarta.

Sukardji,Untung.2015.Pajak Pertambahan nilai.Jakarta:Raja Grafindo Persada

Susanto,Edy.2016.Elektronik Faktur (eFaktur):Apakah Efektif Bagi Pengusaha.Semarang

Resmi Siti, 2015.Perpajakan : Teori dan Kasus, Jakarta:Salemba Empat.

Resmi Siti, 2009.Perpajakan :Teori dan Kasus.Jakarta:Salemba Empat

Waluyo,2009.Perpajakan Indonesia Buuku 2.Jakarta: Salemba Empat.

Yamin Luyiyanto dan Muswati Titi,2009. Model Penyelewengan Pajak Menggunakan Faktur Pajak Fiktif. 